\title{
PENINGKATAN KEMAMPUAN PEMECAHAN MASALAH MATEMATIS SISWA MELALUI METODE TEAMS GAMES TOURNAMENT (TGT) BERBASIS MEDIA PEMBELAJARAN INTERAKTIF
}

\author{
Dewi Silviyani $^{1}$, Runisah $^{2}$, Wiwit Damayanti Lestari ${ }^{3}$ \\ Universitas Wiralodra ${ }^{1,2,3}$ \\ pos-el : dewisilviyani27@gmail.com ${ }^{1}$, runisah_69@yahoo.co.id ${ }^{2}$, \\ wiwitdamayanti28@gmail.com ${ }^{3}$
}

\begin{abstract}
ABSTRAK
Penelitian ini bertujuan untuk mengetahui respon guru dan siswa terhadap penerapan metode pembelajaran Teams Games Tournament (TGT) berbasis media pembelajaran interaktif dan mengetahui apakah penerapan metode pembelajaran Teams games Tournament (TGT) berbasis media interaktif dapat meningkatkan kemampuan pemecahan masalah matematis siswa. Penelitian ini menggunakan metode penelitian kombinasi desain sequential explanatory dimana dapat menggabungkan metode penelitian kualitatif dengan kuantitatif secara berurutan. Berdasarkan hasil penelitian, diperoleh: (1) penerapan metode teams games tournament berbasis media pembelajaran interaktif mendapatkan respon yang positif dari guru dan siswa; (2) penerapan metode teams games tournament berbasis media pembelajaran interaktifsecara signifikan dapat meningkatkan kemampuan pemecahan masalah matematis siswa, hal ini berdasarkan hasil uji-t satusampel yaknit ${ }_{\mathrm{o}}=29,339$ dan $_{\mathrm{k}}=2,036933$ sehinggat $_{\mathrm{o}}>\mathrm{t}_{\mathrm{k}}$ maka menolak $\mathrm{H}_{0}: \overline{\mathrm{D}}=0$, alternatifnya terima $\mathrm{H}_{\mathrm{a}}: \overline{\mathrm{D}}>0$.
\end{abstract}

Kata kunci : metode pembelajaran teams games tounament (TGT), media pembelajaran interaktif, kemampuan pemecahan masalah matematis

\section{ABSTRACT}

The purpose of the study to know the response of teachers and students to the application of the Teams Games Tournament (TGT) learning method based on interactive learning media and find out whether the application of interactive media Teams Games Tournament (TGT) learning methods can improve students' mathematical problem solving abilities. This research uses a combination of sequential explanatory design research methods which can combine qualitative and quantitative research methods in sequence. Based on the research results obtained: (1) the application of teams games tournament method based on interactive learning media get positive responses from teachers and students; (2) the application of teams games tournament method based on interactive learning significantly can improve students' mathematical problem solving abilities, it is based on the result of one sample t- test that $t_{o}=29,339$ and $t_{k}=2,036933$ so thatt ${ }_{o}>t_{k}$ then $\mathrm{H}_{0}: \overline{\mathrm{D}}=0$ rejected, the alternative is accept $\mathrm{H}_{\mathrm{a}}: \overline{\mathrm{D}}>0$.

Keywords : teams games tournament (TGT) method, interactive learning media, mathematical problem solving ability

\section{PENDAHULUAN}

Pemecahan masalah merupakan bagian dari kurikulum matematika yang sangat penting karena dalam proses pembelajaran maupun penyelesaiannya, siswa dimungkinkan memperoleh pengalaman, menggunakan pengetahuan dan keterampilan yang 
sudah dimiliki untuk diterapkan pada pemecahan suatu masalah (Afrida dan Handayani, 2018:33). Halmos (Juanda, Johar, dan Ikhsan, 2014:107) mengatakan bahwa pemecahan masalah adalah jantungnya matematika. Oleh sebab itu, siswa harus selalu dilatih dan dibiasakan berpikir mandiri untuk memecahkan masalah.

Kenyataan yang ada penguasaan materi matematika pada siswa di tingkat pendidikan dasar dan menengah masih rendah. Hal ini dapat dilihat dari indikator: (1) Berdasarkan hasil survei tiga tahunan Program for International Student Assessment (PISA) tahun 2012 oleh Organization for Economic Cooperation and Development (OECD) Indonesia berada di urutan ke 63 dari 64 negara dalam bidang matematika. (2) laporan 2010 World Completitives Yearbook, daya saing SDM Indonesia pada posisi 46 dari 47 negara yang disurvei (Afrida dan Handayani, 2018:33-34). Berdasarkan hasil studi PISA tahun 2012 (Harahap dan Surya, 2017:45) Indonesia menempati peringkat 64 dari 65 negara peserta, atau dengan kata lain menempati peringkat kedua terbawah dari seluruh negara peserta PISA yang disurvey dengan skor rata-rata kemampuan matematika siswa Indonesia yaitu 375, skor tersebut di bawah rata-rata skor internasional yaitu 494. Sejalan dengan hal tersebut berdasarkan hasil wawancara dengan salah satu guru matematika di SMPN 1 Karangampel kemampuan pemecahan masalah matematis siswa masih rendah hal ini dikarenakan kurangnya minat siswa dalam menyelesaikan latihan soal, kebiasaan siswa melihat proses penyelesaian soal dari siswa lain, siswa kurang percaya diri terhadap kemampuan matematikanya, rendahnya minat belajar matematika siswa, dan pemahaman konsep dasar matematika siswa yang masih kurang.

Menurut Sumartini (Cahyani dan Setyawati, 2016:151) untuk meningkatkan kemampuan pemecahan masalah siswa, perlu didukung oleh metode pembelajaran yang tepat. Untuk mengembangkan kemampuan matematika siswa, lingkungan belajar harus didesain sehingga siswa dapat terlibat aktif dalam kegiatan pembelajaran. Metode pembelajaran yang bisa memfasilitasi pengembangan kemampuan pemecahan masalah matematika dengan melibatkan siswa secara aktif dalam pembelajaran diantaranya adalah metode Teams Games Tournament (TGT). Metode pembelajaran Teams Games Tournament (TGT) dapat meningkatkan kemampuan siswa dalam pemecahan masalah sebab dalam model pembelajaran ini keberadaan teman sebaya dalam kelompok belajar dapat mendorong teman lainnya untuk saling aktif dan produktif di kelas (Ibrahim dan Hidayati, 2014:119-120).

Media pembelajaran digunakan untuk komunikasi dan interaksi antara guru dan siswa dalam proses pembelajaran dan seiring dengan perkembangan zaman dan teknologi yang semakin maju, dunia pendidikan dituntut untuk memanfaatkan teknologi dalam pembelajaran (Kristiyono, 2016:2). Guru berperan penting dalam mengembangkan media pembelajaran 
yang inovatif dan mendukung keberhasilan pencapaian tujuan pembelajaran. Cheung dan Slavin (Kristiyono, 2016:4) dalam penelitiannya menemukan bahwa pembelajaran yang mampu menyelesaikan permasalahan dengan menggunakan ICT akan berdampak positif dan dapat meningkatkan keprofesionalan dalam kegiatan belajar mengajar. Sehingga salah satu metode yang dapat digunakan dalam pembelajaran matematika agar lebih variatif adalah penggunaan metode Teams Games Tournament (TGT) berbasis media pembelajaran interaktif. Media pembelajaran interaktif yang digunakan berupa tamplian slide materi pembelajaran yang interaktif yang dibuat menggunakan software Articulate Storyline 3 serta dapat dijalankan menggunakan Adobe Flash Player, GOM Player, atau software lainnya yang dapat menjalankan media dengan format swf.

Tujuan Penelitian ini adalah (1) Mengetahui respon siswa dan guru terhadap penerapan metode pembelajaran Teams Games Tournament (TGT) berbasis media pembelajaran interaktif; (2) Mengetahui apakah penerapan metode pembelajaran Teams games Tournament (TGT) berbasis media interaktif dapat meningkatkan kemampuan pemecahan masalah matematis siswa.

\section{METODE PENELITIAN}

Pada penelitian ini, peneliti menggunakan metode penelitian kombinasi (mixed methods) dengan desain sequential explanatory. Menurut
Sugiyono (Rahma, Sulhadi dan Sumarti, 2016:4) desain sequential explanatory pada metode penelitian kombinasi (mixed methods) dapat menggabungkan metode penelitian kuantitatif dengan kualitatif secara berurutan. Sehingga, pada penelitian ini, untuk menjawab rumusan masalah penelitian yang pertama peneliti menggunakan metode kualitatif, sedangkan untuk menjawab rumusan masalah penelitian yang kedua peneliti menggunakan metode kuantitatif.

\section{Metode Kualitatif}

Objek dalam penelitian ini adalah keseluruhan proses pembelajaran yang menerapkan metode Teams Games Tournament (TGT) berbasis media pembelajaran interaktif. Adapun subjek dalam penelitian ini adalah guru dan siswa kelas IX SMP Negeri 1 Karangampel. Teknik sampling yang digunakan adalah teknik snowball sampling. Informan dalam penelitian ini diantaranya, wakil kepala sekolah bagian kurikulum SMP Negeri 1 Karangampel, guru mata pelajaran matematika kelas IX SMP Negeri 1 Karangampel, Siswa kelas IX SMP Negeri 1 Karangampel. Teknik pengumpulan data pada penelitian ini yaitu, (1) Observasi; (2) Wawancara; (3) Kuesioner. Adapun kriteria interpretasi persentase tanggapan kuesioner sebagai berikut (Zainal Abidin dan Sugeng Purbawanto, 2015:43). 
Tabel 1. Kriteria Interpretasi Persentase Tanggapan Kuesioner

\begin{tabular}{|c|c|}
\hline Kriteria & Persentase \\
\hline Sangat positif & $84 \%<$ skor $\leq 100 \%$ \\
\hline Positif & $68 \%<$ skor $\leq 84 \%$ \\
\hline Biasa & $52 \%<$ skor $\leq 68 \%$ \\
\hline Negatif & $36 \%<$ skor $\leq 52 \%$ \\
\hline Sangat negatif & $\leq 36 \%$ \\
\hline
\end{tabular}

Pada penelitian ini analisis data diambil berdasarkan langkah-langkah analisis data penelitian penelitian kualitatif oleh Mattew B. Miles dan Michael Huberman (1994) diantaranya data reduction, data display, dan conclusion drawing/verification. Triangulasi yang digunakan dalam penelitian ini yaitu, (1) Triangulasi Sumber; (2) Triangulasi Teori; (3) Triangulasi Metodologis.

\section{Metode Kuantitatif}

Populasi dalam penelitian ini adalah siswa SMP kelas IX di SMP Negeri 1 Karangampel Tahun Pelajaran 2019/2020. Sampel dalam penelitian ini adalah sebagian siswa SMP kelas IX di SMP Negeri 1 Karangampel Tahun Pelajaran 2019/2020 yang diambil secara proporsional cluster random sampling. Setiap sampel mempunyai peluang yang sama untuk terpilih, dan pemilihan sampel dilakukan dengan cara pengundian/diundi. Diambil satu kelas dari jumlah kelas IX di SMP Negeri 1 Karangampel. Setelah dilakukan pengundian, terpilih kelas IX E sebagai kelas sampel.

Instrumen pengumpulan data pada metode penelitian kuantitatif yakni berupa soal tes uraian kemampuan pemecahan masalah dengan indikator materi, (1) mengetahui definisi tabung dan kerucut; (2) mengetahui jaringjaring tabung dan kerucut; (3) menemukan rumus luas permukaan tabung dan kerucut; (4) menentukan rumus volume tabung dan kerucut; (5) menyelesaikan masalah kontekstual yang berkaitan dengan luas permukaan dan volume dari gabungan beberapa bangun ruang sisi lengkung.

Uji prasyarat analisis (Uji Normalitas distribusi populasi) di uji dengan menggunakan Uji Liliefors. Teknik uji statistik dalam penelitian ini, diantaranya (1) N-Gain; (2) Uji-t satu sampel. Pada penelitian ini, penentuan kriteria nilai n-gain dikemukakan oleh Hake (Indrie Noor Aini, 2018: 60), yaitu sebagai berikut

Tabel 2. Kriteria N-Gain

\begin{tabular}{|c|c|}
\hline $\mathrm{N}$-gain & Kategori \\
\hline $\mathrm{N}$-gain $>0,7$ & Tinggi \\
\hline $0,3 \leq \mathrm{N}$-gain $\leq 0,7$ & Sedang \\
\hline $\mathrm{N}$-gain $<0,3$ & Rendah \\
\hline
\end{tabular}

Analisis yang dilakukan, menggunakan bantuan Microsoft Office excel 2010 dan IBM SPSS Statistics 20. Hipotesis statistik dalam penelitian ini adalahH $_{0}: \overline{\mathrm{D}}=0, \mathrm{H}_{\mathrm{a}}: \overline{\mathrm{D}}>0$. Kriteria keputusan pengujian hipotesis yakni, tolak $H_{o}$ jika $t_{o}>t_{k}$ dan terima $H_{o}$ jika $\mathrm{t}_{\mathrm{o}}<\mathrm{t}_{\mathrm{k}}$. Pada uji $\mathrm{t}$ satu sampel dengan IBM SPSS Statistics 20, test value $=0$ karena pada penelitian ini peneliti tidak ingin membandingkan nilai hasil tes siswa dengan suatu nilai tertentu

\section{HASIL DAN PEMBAHASAN}

Selama dan setelah kegiatan pembelajaran dilakukan, peneliti melakukan observasi, wawancara, dan kuesioner yang berkaitan dengan respon guru dan siswa terhadap penerapan metode pembelajaran Teams Games Tournament (TGT) berbasis media pembelajaran interaktif. Peneliti juga melakukan pre tes dan pos tes kemampuan pemecahan masalah matematis siswa pokok bahasan bangun ruang sisi lengkung untuk mengetahui apakah terdapat peningkatan kemampuan pemecahan masalah 
matematis siswa. Respon guru terhadap pembelajaran dilakukan dengan observasi oleh guru selama kegiatan pembelajaran berlangsung dan wawancara setelah kegiatan pembelajaran berlangsung. Respon siswa terhadap pembelajaran, dilakukan dengan melakukan wawancara dua orang siswa yang mempunyai hasil pre tes kemampuan pemecahan masalah matematis tinggi dan rendah, serta dengan menggunakan kuesioner respon siswa terhadap penerapan metode pembelajaran Teams Games Tournament (TGT) berbasis media pembelajaran interaktif.

Berdasarkan hasil observasi oleh guru matematika terhadap peneliti selama melakukan kegiatan pembelajaran yang menerapkan metode pembelajaran Teams Games Tournament (TGT) berbasis media pembelajaran interaktif pada pokok bahasan bangun ruang sisi lengkung didapatkan hasil observasi yakni, pada pertemuan I hasil observasi yang dilakukan oleh guru menunjukkan bahwa aspek yang diamati pada kategori persiapan peneliti telah memenuhi kriteria aspek yang diamati diantaranya, peneliti membuat RPP, peneliti menyiapkan media pembelajaran yang akan digunakan, peneliti menyiapkan sumber dan alat pembelajaran yang dibutuhkan. Aspek selanjutnya yang diamati yaitu aspek pada kategori penyajian, peneliti dinilai sudah melakukan penyajian pembelajaran dengan cukup baik walaupun peneliti dinilai kurang maksimal pada aspek siswa berpartisipasi aktif. Aspek terakhir yang diamati yaitu aspek pada kategori kondisi media pembelajaran interaktif, peneliti dinilai belum membuat media pembelajaran yang sesuai dengan tingkat berpikir siswa, materi yang disajikan dalam media pembelajaran masih kurang dalam hal mengilustrasikan konsep bangun ruang sisi lengkung tabung walaupun sudah sesuai dengan tujuan pembelajaran yang dilakukan. Pada pertemuan II hasil observasi yang dilakukan oleh guru menunjukkan bahwa aspek yang diamati pada kategori persiapan, peneliti telah memenuhi kriteria aspek yang diamati diantaranya, peneliti membuat RPP, peneliti menyiapkan media pembelajaran yang akan digunakan, peneliti menyiapkan sumber dan alat pembelajaran yang dibutuhkan. Pada kategori penyajian, peneliti dinilai sudah melakukan penyajian pembelajaran dengan lebih baik dibandingkan dengan pertemuan sebelumnya, walaupun guru menilai bahwa ada beberapa hal dalam pembelajaran yang belum sepenuhnya maksimal dilakukan oleh peneliti seperti pada aspek siswa berpartisipasi aktif dalam pembelajaran, hal tersebut belum sepenuhnya maksimal karena masih terdapat beberapa siswa yang pasif walaupun sudah lebih baik dari pertemuan sebelumnya. Aspek terakhir yang diamati yaitu aspek pada kategori kondisi media pembelajaran interaktif, peneliti dinilai sudah membuat media pembelajaran yang sesuai dengan tingkat berpikir siswa dan sesuai dengan tujuan pembelajaran yang dilakukan. Pada pertemuan III dan IV, hasil observasi yang dilakukan oleh guru 
menunjukkan bahwa aspek yang diamati pada kategori persiapan, peneliti dinilai sudah melakukan persiapan pembelajaran dengan baik. Aspek selanjutnya yang diamati yaitu aspek pada kategori penyajian, peneliti dinilai sudah melakukan penyajian pembelajaran dengan baik, pada kategori penyajian peneliti telah memenuhi kriteria aspek yang diamati. Aspek terakhir yang diamati yaitu aspek pada kategori kondisi media pembelajaran interaktif, peneliti dinilai sudah membuat media pembelajaran yang sesuai dengan tingkat berpikir siswa dan sesuai dengan tujuan pembelajaran yang dilakukan. Observasi dilakukan oleh guru selama peneliti melakukan kegiatan pembelajaran.

Berdasarkan hasil wawancara peneliti dengan guru matematika diperoleh respon guru matematika bahwa penerapan metode pembelajaran Teams Games Tournament (TGT) berbasis media pembelajaran interaktif yang dilakukan peneliti dalam pembelajaran matematika sudah cukup baik. Menurut guru matematika, penyajian soal latihan matematika yang disajikan dengan menggunakan media pembelajaran interaktif dan pembelajaran dengan metode teams games tournament (TGT) dinilai dapat meningkatkan antusias siswa dalam pemecahan masalah soal, karena pembelajaran secara berkolompok memungkinkan siswa untuk dapat saling berdiskusi mencari pemecahan soal yang diberikan, dan juga penyajian soal dengan media pembelajaran interaktif dapat membantu siswa dalam memahami soal yang diberikan serta meningkatkan antusias siswa untuk mengerjakannya. Sehingga, apabila siswa antusias dalam mengerjakan soal yang diberikan maka kemampuan pemecahan masalah matematis siswa dapat meningkat. Secara keseluruhan respon yang diberikan oleh guru matematika yaitu penerapan metode Teams Games Tournament (TGT) berbasis media pembelajaran interaktif dapat meningkatkan kemampuan pemecahan masalah matematiks siswa, serta media pembelajaran interaktif yang digunakan peneliti dalam menyajikan soal matematika dapat mendorong siswa untuk lebih termotivasi dalam mencari pemecahan masalah soal yang disajikan, serta inovasi baru dalam pembelajaran matematika membuat siswa lebih senang dan antusias dalam mengikuti kegiatan pembelajaran yang dilakukan, sehingga penerapan metode pembelajaran Teams Games Tournament (TGT) berbasis media pembelajaran interaktif dapat berpengaruh terhadap pemahaman materi siswa, keterlibatan aktif siswa dalam pembelajaran, dan kemampuan pemecahan masalah matematis siswa.

Berdasarkan hasil wawancara dengan dua orang siswa yang mempunyai hasil pre tes kemampuan pemecahan masalah matematis tinggi dan rendah, kedua siswa berpendapat bahwa keduanya cenderung menyukai pembelajaran matematika dengan konsep permainan, selain karena jarang dilakukan dalam pembelajaran matematika, permainan dalam pembelajaran matematika juga dapat 
$\begin{array}{llr}\text { menciptakan } & \text { suasana } & \text { belajar } \\ \text { matematika } & \text { menjadi } & \text { lebih }\end{array}$ menyenangkan, keduanya juga lebih menyukai pembelajaran secara berkelompok karena memungkinkan siswa untuk saling bekerjasama, dan bertukar pikiran selama kegiatan pembelajaran berlangsung, serta penggunaan media pembelajaran interaktif dalam pembelajaran matematika dapat memudahkan siswa dalam memahami materi yang disampaikan dan penyajian soal matematika dengan menggunakan media pembelajaran interaktif dapat membantu siswa dalam memahami soalmatematika yang disajikan karena penyajian soal matematika dengan ilustrasi berupa gambar bergerak menjadikan soal lebih mudah dipahami. Sehingga didapatkan kesimpulan bahwa penerapan metode pembelajaran Teams Games Tournament (TGT) berbasis media pembelajaran interaktif sudah memenuhi kriteria pembelajaran yang diharapkan oleh siswa, atau pembelajaran yang disenangi oleh siswa. Wawancara dilakukan setelah peneliti melakukan tindakan penelitian. Tindakan penelitian dalam penelitian ini, yakni penerapan metode pembelajaran Teams Games Tournament (TGT) berbasis media pembelajaran interaktif pada pokok bahasan bangun ruang sisi lengkung.

Berdasarkan hasil kuesioner respon siswa terhadap penerapan metode pembelajaran Teams Games
Tournament (TGT) berbasis media pembelajaran interaktif pada pokok bahasan bangun ruang sisi lengkung, diperoleh bahwa persentase tanggapan kuesioner respon siswa terhadap penerapan metode pembelajaran Teams Games Tournament (TGT) berbasis media pembelajaran interaktif yang terbanyak berada pada kriteria positif, yaitu sebanyak 24 siswa atau $73 \%$ dari jumlah responden atau jumlah siswa. Pada rentang skor persentase tanggapan kuesioner kategori sangat positif, diperoleh terdapat sebanyak 4 siswa atau $12 \%$ dari jumlah responden atau jumlah siswa, sedangkan pada rentang skor persentase tanggapan kuesioner kategori biasa terdapat sebanyak 5 siswa atau $15 \%$ dari jumlah responden atau jumlah siswa. Jadi, berdasarkan persentase tanggapan kuesioner respon siswa terhadap penerapan metode pembelajaran Teams Games Tournament (TGT) berbasis media pembelajaran interaktif, diperoleh bahwa kecenderungan respon siswa terhadap penerapan metode pembelajaran Teams Games Tournament (TGT) berbasis media pembelajaran interaktif berada pada kriteria positif, artinya sebagian besar siswa yakni sebanyak 24 siswa dari 33 siswa atau $73 \%$ dari jumlah siswa merespon positif terhadap penerapan metode pembelajaran Teams Games Tournament (TGT) berbasis media pembelajaran interaktif pada pembelajaran matematika. 
Tabel 3. Persentase Tanggapan Kuesioner Respon Siswa

\begin{tabular}{|c|c|c|c|}
\hline No & Persentase & Frekuensi & Kriteria \\
\hline 1 & $84 \%<$ skor $\leq 100 \%$ & 4 & Sangat positif \\
\hline 2 & $68 \%<$ skor $\leq 84 \%$ & 24 & Positif \\
\hline 3 & $52 \%<$ skor $\leq 68 \%$ & 5 & Biasa \\
\hline 4 & $36 \%<$ skor $\leq 52 \%$ & - & Negatif \\
\hline 5 & $\leq 36 \%$ & - & Sangat negatif \\
\hline \multicolumn{2}{|c|}{ Jumlah } & 33 & \\
\hline
\end{tabular}

Data hasil penelitian peningkatan kemampuan pemecahan masalah matematis siswa yang diperoleh dari penelitian ini diantaranya adalah data hasil nilai pre tes, pos tes dan skor $\mathrm{N}$ -
Gain kemampuan pemecahan masalah matematis siswa. Adapun data hasil penelitian tersebut dapat dilihat pada tabel berikut.

Tabel 4. Data Hasil Penelitian

\begin{tabular}{|c|c|c|c|c|}
\hline & Pre tes & Postes & N-Gain & Kategori \\
\hline Skor Tertinggi & 76 & 94,67 & & \\
\cline { 1 - 3 } Skor Terendah & 25,33 & 56 & \multirow{2}{*}{0,59} & \multirow{2}{*}{ Sedang } \\
\cline { 1 - 3 } Rata-rata & 52,36 & 80,69 & & \\
\hline
\end{tabular}

(Nilai Maksimum Pre tes dan Pos tes: 100, Skor maksimum N-Gain: 1)

Pada penelitian ini, ditentukan terlebih dahulu acuan penilaian sebelum menjelaskan hasil pre tes dan pos tes, serta peningkatan kemampuan pemecahan masalah matematis siswa (N-Gain). Hal ini dilakukan untuk mengetahui seberapa besar pencapaian ketuntasan siswa dalam pembelajaran pokok bahasan bangun ruang sisi lengkung. Pada akhirnya dapat diketahui peningkatan kemampuan pemecahan masalah matematis siswa dalam hal ini peningkatan kemampuan pemecahan masalah matematis siswa melalui metode Teams Games Tournament (TGT) berbasis media pembelajaran interaktif. Uji normalitas bertujuan untuk prasyarat uji parametrik dan untuk mengetahui sebaran data berdistribusi normal. Pada penelitian ini didapat hasil uji normalitas sebagai berikut.

Tabel 5. Hasil Uji Normalitas

\begin{tabular}{|c|c|c|c|}
\hline & Lo & $\mathrm{L}_{(0,05,33)}$ & Keterangan \\
\hline Pre tes & 0,106 & 0,151 & Normal \\
\hline Postes & 0,071 & 0,151 & Normal \\
\hline N-Gain & 0,104 & 0,151 & Normal \\
\hline
\end{tabular}

Berdasarkan tabel 5, menunjukkan bahwa pada hasil pre tes diperoleh Lo $=$ 0,106 dan $\mathrm{L}_{(0,05,33)}=0,151$, pada hasil pos tes diperoleh $\mathrm{Lo}=0,071$ dan $\mathrm{L}_{(0,05}$, 33) $=0,151$, dan pada hasil N-Gain diperoleh $\mathrm{Lo}=0,104$ dan $\mathrm{L}_{(0,05,33)}=$ 0,151 dengan taraf signifikansi $(\alpha)=$ 0,05, karena Lo $<$ Lk, gagal menolak/menerima Ho. Artinya sampel berasal dari populasi yang berdistribusi normal.

Setelah uji normalitas dipenuhi, maka selanjutnya dilakukan uji dengan menggunakan uji-t satu sampel. Hal ini bertujuan untuk mengetahui peningkatan kemampuan pemecahan 
masalah matematis siswa melalui berbasis media pembelajaran interaktif. metode teams games tournament

Tabel 6. Hasil Statistik Uji-t Satu Sampel

\begin{tabular}{|c|c|c|c|c|}
\hline \multicolumn{5}{|c|}{ One-Sample Statistics } \\
\hline & N & Mean & Std. Deviation & Std. Error Mean \\
\hline Skor N-Gain KPMM & 33 &, 6054 &, 13911 &, 02422 \\
\hline
\end{tabular}

Tabel 7. Hasil Uji-t Satu Sampel

\begin{tabular}{|l|c|c|c|c|c|c|}
\hline \multicolumn{7}{|c|}{ One-Sample Test } \\
\hline & \multicolumn{7}{|c|}{ Test Value = 0 } \\
\cline { 2 - 6 } & $\mathrm{T}$ & Df & $\begin{array}{c}\text { Sig. (2- } \\
\text { tailed) }\end{array}$ & $\begin{array}{c}\text { Mean } \\
\text { Difference }\end{array}$ & \multicolumn{2}{|c|}{$\begin{array}{c}\text { 55\% Confidence Interval } \\
\text { of the Difference }\end{array}$} \\
\cline { 5 - 7 } & & 32 &, 000 &, 60539 &, 5561 &, 6595 \\
\hline $\begin{array}{l}\text { Skor N-Gain } \\
\text { KPMM }\end{array}$ & 24,999 & 32 & & & Upper \\
\hline
\end{tabular}

Uji-t satu sampel ini menguji $\mathrm{H}_{0}: \overline{\mathrm{D}}=0$ tehadap $\mathrm{H}_{\mathrm{a}}: \overline{\mathrm{D}}>0$. Nilai uji-t yang didapat $t_{0}=24,999$ dengan derajat kebebasan $=n-1=33-1=$ 32 dengan $t_{k}=2,036933$ sehingga karena kitat $_{\mathrm{o}}>\mathrm{t}_{\mathrm{k}}$ maka menolak $\mathrm{H}_{0}: \overline{\mathrm{D}}=0$ alternatifnya terima $\mathrm{H}_{\mathrm{a}}: \overline{\mathrm{D}}>$ 0 . Sehingga, dapat disimpulkan bahwa penerapan metode teams games tournament berbasis media pembelajaran interaktif dapat meningkatkan kemampuan pemecahan masalah matematis siswa.

\section{KESIMPULAN}

Berdasarkan hasil penelitian dan pembahasan yang diuraikan, maka peneliti mengambil kesimpulan sebagai berikut, (1) Penerapan metode teams games tournament berbasis media pembelajaran interaktif mendapatkan respon yang positif dari guru dan siswa. Guru dan siswa memberikan respon, bahwa penerapan metode teams games tournament berbasis media pembelajaran interaktif dapat meningkatkan keterlibatan aktif siswa dalam pembelajaran, pemahaman siswa terhadap materi pembelajaran, menciptakan suasana pembelajaran yang lebih interaktif, dan dapat meningkatkan kemampuan pemecahan masalah matematis siswa; (2)Penerapan metode teams games tournament berbasis media pembelajaran interaktif dapat meningkatkan kemampuan pemecahan masalah matematis siswa.

Berdasarkan hasil penelitian dan kesimpulan, maka peneliti ingin memberikan saran agar dapat menerapkan metode teams games tournament berbasis media pembelajaran interaktif dalam pembelajaran karena dapat meningkatkan kemampuan pemecahan masalah matematis siswa, diharapkan sebagai bahan pertimbangan untuk diajukan kepada guru matematika supaya dapat mencoba menerapkan metode teams games tournament berbasis media pembelajaran interaktif dalam pembelajaran matematika di kelas, dan dapat ditindaklanjuti hasil penelitian ini dengan jumlah sampel yang sama ataupun berbeda. Selain itu, untuk memperoleh hasil penelitian yang 
maksimal diperlukan alokasi waktu yang lebih lama serta dilakukan pada pokok bahasan yang berbeda dan jenjang pendidikan yang berbeda dengan subjek yang lebih luas.

\section{DAFTAR PUSTAKA}

Abidin, Z., \& Purbawanto, S. (2015). Pemahaman Siswa terhadap Pemanfaatan Media Pembelajaran Berbasis Livewire pada Mata Pelajaran Teknik Listrik Kelas X Jurusan Audio Video di SMK Negeri 4 Semarang. Edu Elektrika Journal, 4(1).

Afrida, A. N. dan Handayani, S. (2018). Meningkatkan Kemampuan Pemecahan Masalah Matematika dan Rasa Ingin Tahu Siswa Kelas XI Melalui Model ARIAS. Prosiding Seminar Nasional Pendidikan Matematika Universitas Negeri Semarang

Cahyani, H. dan Setyawati, R. W. (2016). Pentingnya Peningkatan Kemampuan Pemecahan Masalah melalui PBL untuk Mempersiapkan Generasi Unggul Menghadapi MEA. Prosiding Seminar Nasional Matematika X Universitas Negeri Semarang.

Harahap, E. R. dan Surya, E. (2017). Kemampuan Pemecahan Masalah Matematis Siswa Kelas VII Dalam Menyelesaikan Persamaan Linear Satu Variabel. Edumatica, 7(1): 4454
Ibrahim dan Hidayati, N. (2014). Pengaruh Model Pembelajaran Teams Games Tournament (TGT) Terhadap Peningkatan Kemampuan Pemecahan Masalah Matematika Ditinjau Dari Kemampuan Awal Siswa SMA Negeri 1 Seyegan. Jurnal AgriSains, 5(2): 115-136

Aini, I. N. (2018). Analisis Kemampuan

Berpikir Kreatif Matematis Siswa Berdasarkan Pengetahuan Awal Matematis. Prima: Jurnal Pendidikan Matematika, 2(1), 5766.

Juanda, Johar, dan Ikhsan. (2014). Peningkatan Kemampuan Pemecahan Masalah dan Komunikasi Matematis Siswa SMP melalui Model Pembelajaran Means-ends Analysis (MeA). Jurnal Kreano, 5(2): 105-113

Kristiyono, A. (2016). Pengembangan Multimedia Interaktif Berbasis Problem Solving Pada Siswa Kelas XI SMAN 1 Suruh Kab. Semarang. Tesis. Surakarta: Universitas Muhammadiyah Surakarta

Miles, M. B., \& Huberman, A. M. (1994). Qualitative data analysis: An expanded sourcebook. sage.

Rahma, A. D., Sulhadi dan Sumarti, S. S. (2016). Implementasi Pembelajaran Sains Dengan Media Fotonovela Untuk Meningkatkan Motivasi Belajar Siswa SD/MI. Journal of Primary Education, 5(1): 1-9. 